\section{Category}

Synthesis of

Materials and

Unnatural Products

\section{Key words}

triazoles

regioselectivity

tetrazoles

photochemistry
S. STEWART, R. HARRIS,* C. JAMIESON* (GLAXOSMITHKLINE MEDICINES RESEARCH CENTRE, STEVENAGE AND UNIVERSITY OF STRATHCLYDE, GLASGOW, UK)

Regiospecific Synthesis of N2-Aryl 1,2,3-Triazoles from 2,5-Disubstituted Tetrazoles via Photochemically Generated Nitrile Imine Intermediates

Synlett 2014, 25, 2480-2484.

\title{
Triazole Your Tetrazoles
}

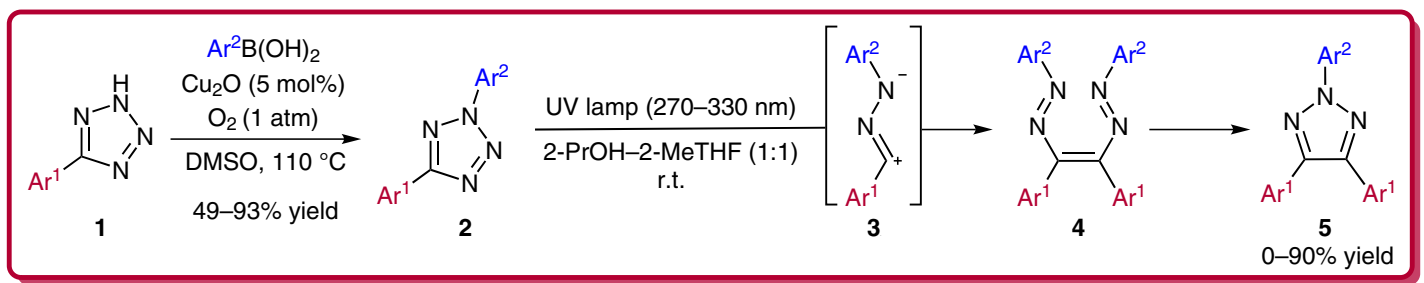

Selected examples of $\mathbf{5}$ :

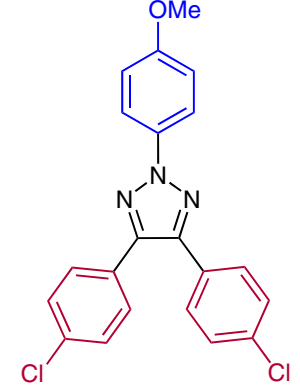

$67 \%$ yield $16 \mathrm{~h}$<smiles>c1ccc(-c2nc(-c3ccccc3)n(-c3ccccc3)n2)cc1</smiles>

$19 \%$ yield $24 \mathrm{~h}$



$38 \%$ yield $30 \mathrm{~h}$<smiles>O=[N+]([O-])c1ccc(-n2nc(-c3ccccc3)c(-c3ccccc3)n2)cc1</smiles>

$0 \%$ yield $>100 \mathrm{~h}$<smiles>COc1ccc(-c2nn(-c3ccc(OC)cc3)nc2-c2ccc(OC)cc2)cc1</smiles><smiles>CCOC(=O)c1ccc(-n2nc(-c3ccccc3)c(-c3ccccc3)n2)cc1</smiles>

$90 \%$ yield

$7 \mathrm{~h}$

$14 \%$ yield $23 \mathrm{~h}$<smiles>N#Cc1cccc(-n2nc(-c3ccccc3)c(-c3ccccc3)n2)c1</smiles>

$0 \%$ yield $24 \mathrm{~h}$
Significance: Stewart, Harris, and Jamieson developed a one-step reaction to photochemically synthesize N2-aryl 1,2,3-triazoles 5 from 2,5-diaryl tetrazoles $\mathbf{2}$. This method bypasses issues of regioselectivity by first preparing the appropriate $\mathrm{N}$-arylated tetrazole, which under UV irradiation forms a nitrile imine intermediate $\mathbf{3}$ that dimerizes and rearranges to produce the appropriate N2aryl 1,2,3-triazole.

SYNFACTS Contributors: Timothy M. Swager, Sarah P. Luppino Synfacts 2015, 11(1), $0030 \quad$ Published online: 15.12.2014 DOI: 10.1055/s-0034-1379669; Reg-No.: S12814SF
Comment: Electron-donating substituents and dilute conditions led to improved yields of the triazoles, while electron-deficient $N$-aryl substituents led to poor or zero conversion. Previous studies of similar starting materials identified tetrazine as the final product, but the authors indicate that the only other compound isolated in their study was the Wanzlick dimer $\mathbf{4}$, which can be converted into the final triazole with additional UV irradiation. 